\title{
RACE, POWER, AND PLACE: LAKOTA LESSONS FROM PINE RIDGE RESERVATION
}

\author{
Christey Carwile
}

\section{Abstract}

Drawing on three years of partnership with residents of the Pine Ridge Reservation in South Dakota, I discuss some of the insights and challenges of working toward a critical community engagement that is antiracist, anti-colonial, and "place-engaged" (Siemers et al., 2015). I specifically reflect on bow the bridging of academic practice with Indigenous models of teaching and learning can offer a powerful way to center social justice in community engagement work. I model this approach by discussing academic concepts and pedagogies used in the classroom alongside Lakota concepts and stories shared during our engagement. I then include the voices of students as they critically reflect on lessons of racial privilege, Indigenous survivance, and reciprocity/allyship. Lastly, this article is my own attempt at some form of reciprocation, as a way to respond to the common expectation that many Lakota elders/teachers expressed during our time with them-that we share these lessons beyond the Reservation.

\section{Introduction}

Every year, approximately three million tourists visit Mount Rushmore, located in the Black Hills of South Dakota. Here one can gaze up at the massive faces of George Washington, Thomas Jefferson, Abraham Lincoln, and Theodore Roosevelt carved into the granite mountainside towering over 5,000 feet above sea level. The site is purported by the National Park Service to bring visitors "face to face with the rich heritage we all share" (National Park Service, n.d.). What is not highlighted in the national narrative of Mount Rushmore, however, is that the land on which the memorial sits belonged/s to the Lakotas. Referred to among them as Paba Sapa (Black Hills), it was, and continues to be, regarded as sacred land that is deeply tied to Lakota origin stories, history, and identity. In 1851 and 1868, the U.S. government conferred title of the land to the Lakotas; however, after General George Custer announced the discovery of gold in the region, the government illegally seized Paba Sapa in 1877. While Mount Rushmore is famed as a patriotic symbol of American history, for the Lakotas, the blasting of stolen sacred land to carve the faces of settler nation leaders is easily viewed as a symbol of white supremacy. 
When students carry out community engagement work on Pine Ridge Reservation-an Oglala Lakota Reservation just over 80 miles south of where Mount Rushmore stands-they hear this counter-narrative many times from elders living “on Rez," and they are prepared for it. They have read about the importance of land and place for Lakotas and for Indigenous peoples in general, and they have read about settler colonialism's enduring justifications for disappearing Indigenous peoples in order to attain their lands as property (V. Deloria, 1969; Dunbar-Ortiz, 2014). Yet, they are no longer in the classroom of an academic institution; they are on the second largest Native American reservation in the United States, where book knowledge gives way to stories, oral traditions, and local opinions that are mediated by cultural elders rather than professors. This cultural knowledge is deeply place-based and rooted in the landscape of the Reservation and original Native lands. As Dakota scholar and activist Vine Deloria Jr. describes it, "American Indians hold their lands - places - as having the highest possible meaning, and all their statements are made with this reference point in mind" (2003, p. 61).

For this reason, it is imperative that community service learning between students and Native peoples living on reservations foreground the value and importance of place, as well as the Indigenous ways of teaching and learning that are embedded in those places. Drawing on three years of partnership with community members on Pine Ridge Reservation, I discuss some of the insights and challenges of working toward a critical community engagement that is anti-racist, anti-colonial, and "place-engaged" (Siemers et al., 2015). Critical place inquiry (Tuck \& McKenzie, 2015) provides the context for this research, as it involves questions and methodological approaches that are deeply informed by the complex interrelationship between people and places. As Tuck and McKenzie (2015) specifically note, "decolonizing conceptualizations of land and place and Indigenous methods are central, not peripheral, to practices of critical place inquiry" (p. 19). Engaging in place requires us to be attuned to the knowledge, methodologies, and stories that are embedded in those places and thus centering them in community engagement practice.

Santiago-Ortiz's (2019) “anti-colonial stance” in critical community service learning, is helpful here as it calls for both "the acknowledgment of settler-colonialism as a distinct and continuing structure in academic spaces and beyond" and "incorporating anticolonial and decolonizing methodologies that counter and resist dominant narratives” (p. 48). Indeed, understanding Pine Ridge as place involves coming to terms with the complex history of settler colonialism in the United States as well as how our own identities might be implicated in this process as either settlers, the colonized, or a combination of both (Patel, 2016; Santiago-Ortiz, 2019). In addition, conceptions of place on the Reservation are taught through specific Lakota methodologies and concepts. Thus, during community engagement and community service learning, it is important to attend not only to what students learn but also to where and how they learn it. Using Pine Ridge as an example, I hope to show how bridging traditional academic practice with Indigenous models of teaching and learning can be a powerful way to center social justice in community engagement work.

\section{Background and Context}

Warren Wilson College has had a long-standing relationship with community partners on the Pine Ridge Reservation, having facilitated eight service projects there since 2008. This relationship was first developed through 
the food security work of an individual student and eventually became fostered by faculty, staff, and students over the years through a bi-annual Cultural Psychology service learning course and occasional week-long service break trips. These visits stemmed from open invitations by Indigenous elders on the Reservation who also collaborated in deciding which projects would best meet community needs. Invitation by elders was and continues to be an important component of our engagement on the Reservation.

When the faculty member who taught the Cultural Psychology service course left her position for another job continuing food sovereignty work on the Reservation, I accepted her offer to continue the college's relationship with Pine Ridge. As an anthropologist who had done most of my cross-cultural research in West Africa, it was a bit of a leap to take students to a Native American reservation. Reflecting on a previous study abroad course I led to Ghana, I thought of how easily students were able to avoid discomfort and racial privilege during their service with primary and secondary school students in Accra. Even at Ghana's infamous coastal slave forts, tour guides and locals never brought up race, racism, or colonization unless someone explicitly asked about it. While Warren Wilson is a progressive liberal arts institution with a strong focus on social justice education, it is also a predominantly white institution where white students can avoid confronting their own racial privilege unless they themselves or the courses they take intentionally facilitate it. On the Reservation, there is simply no avoiding it. Like Ghana's slave forts, the very existence of the Reservation is an obvious legacy of white racial privilege; however, Lakota pedagogy insists on a constant critique of white settler colonialism. Students would need to be prepared for a very particular kind of community engagement, one in which they critically examined their own place-based identities and in which discomfort played a central role in their learning. As Green (2003) notes, it can be easy for white students to walk away from service with a story of feeling good about serving others, rather than a story of white privilege, racial difference, and social inequality.

I first visited the Pine Ridge Reservation in the summer of 2016 along with the previous faculty member and two alumni, all of whom had continued to visit and maintain strong relationships with residents there. I was introduced to community partners and elders, including religious leaders, activists, teachers, and their families. In the fall of 2016, I accompanied 10 students to Pine Ridge as part of a service learning break trip offered as a two-credit anthropology course. This trip served as a pilot in order for me to experiment with different pedagogies and feel out some of the challenges of community engagement on the Reservation. As an anthropologist, it was crucial for me to visit the Reservation as much as possible outside of classes to maintain relationships there and to understand as much of the reality of this place that I possibly could as an outsider. As a place known on a national level primarily for its high rates of poverty, diabetes, alcoholism, and suicide, I was invited into the community with caution, warmth, and humor and all with a constant awareness of the politics of my own identity.

In the fall of 2018, I incorporated this one-week visit to Pine Ridge into a new upper-level anthropology elective titled Race, Power, and Place. The course counts as a social justice and service learning elective, which are both part of the college's Civic Identity Values. Drawing from cultural anthropology, cultural geography, and critical race theory, the course examines the intersections of racial/ethnic identity and cultural understandings of power and place. We examine how race and power are inscribed in the built environment and in the natural landscape and how certain places marginalize and oppress certain identities while others affirm and uphold them. Students conduct ethnographic research of local places in the surrounding Asheville area or in their home places 
and are required to write a critical ethnography of place that discusses the connections between identity, power, and place. During our mid-semester fall break, we traveled to Pine Ridge Reservation for seven days where we lodged at the Red Cloud Renewable Energy Center on the property of Henry Red Cloud, owner of Lakota Solar Enterprises and fifth-generation descendant of Chief Red Cloud. Residing on Henry's land meant that we were surrounded by multiple generations of family members and had a community space for sharing meals and hosting other residents of the Reservation. The property, lying along the banks of White Clay Creek and surrounded by rolling hills, also offered a profound space for reflecting on our experiences each day.

\section{Critical Community Engagement in Place}

During our first engagement experience on the Reservation in 2016, I worked with the community partner that was already in place - a Colorado-based non-profit focusing on hunger relief and directed by an alum who first established the college's partnership on the Reservation. Much of our work involved stocking food pantries, delivering donated food to local schools, and assisting at community donation events. Because Pine Ridge Reservation is considered a food desert, with only one grocery store and limited access to healthy foods, our work was openly appreciated by community members. However, as I thought through the complex power dynamics that existed while doing this kind of community engagement on the Reservation-we were a non-Native group providing food mediated by a non-Native organization that was paid from student fees and donations managed by an academic institution-it became clear to me that it would need to look different if I planned to continue taking students in the future. My goal for our next engagement was to work directly with Pine Ridge residents and to ensure that the entirety of the budget, after paying for our own food and travel, was invested directly into the Reservation. Therefore, in 2018, our engagement was determined by our primary community engagement coordinator - a Pine Ridge resident, activist, and elder who has been involved in facilitating community engagement efforts for the college from the outset. In a previous visit to the Reservation, I met with her to discuss my ideas and goals for the course and to ask if she would be willing to coordinate our engagement with full discretion in determining our schedule for the week. In this way, I hoped to address power imbalances by following her lead on what our community engagement would entail. This time our engagement included floating in Lakota Language Immersion schools, helping to re-side and repair trailers from hailstorm damage, painting the interior of the Reservation's radio station, participating in beading and dance workshops, making dinners for community members, and spending many hours listening to elders speak about Lakota history and culture.

As I will expand upon later, our experiences on the Pine Ridge Reservation deeply problematized the notion of service, particularly the distinction between those who serve and those who are served or between those who give and those who receive. This was one of the areas that students grappled with the most in their reflections upon returning from the Reservation. In addition, the term "service" carries many different and often problematic connotations on the Reservation as it is typically associated with missionary agendas that evoke a long and traumatic history for Indigenous peoples. For these reasons, I refer to our work in the classroom and on the Reservation as critical community engagement, choosing not to use the term "service." In the same vein as critical 
service learning, critical community engagement promotes social change by encouraging students "to investigate and understand the root causes of social problems and the courses of action necessary to challenge and change the structures that perpetuate those problems” (Mitchell, 2008, p. 53). In addition, it urges students to consider "the impact of their own personal action/inaction" in either perpetuating or transforming those social problems (Mitchell, 2008, p. 54). This approach falls directly in line with what Grain and Lund (2016) refer to as the "social justice turn" in service learning. This involves "(a) the problematization of charity and salvationism; (b) a critique of White normativity paired with the burgeoning diversification of authors and perspectives; and (c) a pedagogical and curricular embrace of emotions-especially those related to tension, ambiguity, and discomfort” (2016, p. 46).

Teaching this course from an anti-racist and anti-colonial framework also required addressing the social construction of race and the history of racism in the United States (Omi \& Winant, 2015), as well as discussing settler colonialism and white supremacy as enduring structures that shape all social institutions in the United States, including academia (Dunbar-Ortiz, 2014; Santiago-Ortiz, 2019). In addition, critical community engagement involves humility through a constant analysis of power relations and imbalances, a radical openness to outside critique, individual and collaborative critical reflection, and a willingness to follow the lead of our community partners.

Community engagement happens in place and places are laden with power relations. Gupta and Ferguson (1997) note that, it "is not simply that one is located in a certain place but that the particular place is set apart from and opposed to other places" (p. 13). Places are given cultural meanings by their inhabitants as well as by outsiders, and they carry important signifiers about social relations, histories, and identities. They can be invented, imagined, and, as with sites such as Mount Rushmore, contested. They may serve as sites of empowerment for some or as exotic subjects of dominant curiosities for others. Therefore, we cannot only learn about place; we must also learn through place (Siemers et al., 2015, p. 102).

Community engagement and service learning practitioners are increasingly theorizing and attending to place as a way to deepen student learning, develop stronger connections with the communities we engage with, and more fully analyze how power is inscribed in community geographies (Bailey, 2017; Clark \& Young, 2005; Gruenewald, 2003; Siemers et al., 2015; Yamamura \& Koth, 2018). For instance, Gruenewald’s (2003) “placeconscious" approach to service learning assumes that places are never neutral. When we fail to problematize and deconstruct place, we become complicit in the power hierarchies and political processes that brought these places into being. Indeed, the very existence of Native reservations in the United States is a particularly strong reminder of this point.

My writing here is inspired by the more recent and highly comprehensive project of critical place inquiry (Tuck \& McKenzie, 2015), particularly in its goals of bridging studies of place in the social sciences with decolonizing research and Indigenous methodologies. Furthermore, critical place inquiry involves approaches that are not only deeply informed by the relationship between social life and place but also "seek to be a form of action in responding to critical place issues," including settler colonialism (Tuck \& McKenzie, 2015, p. 2). In this article, as in the classroom, I draw primarily on studies of place from anthropology, cultural geography, and critical race 
theory as a way to frame our engagement on the Reservation. As I will turn to later, understanding people's sense of place (Feld \& Basso, 1996) and how and why people are attached to place (Low, 1992) can be an invaluable methodology for critical community engagement by recognizing the stories and voices that emerge from places as well as the power relations that inform and/or work to erase those stories and voices. Thus, studying place means not only paying attention to stories of place but to stories in place, and this is where, I believe, community engagement has the potential to provide valuable insights as it mediates these two domains.

\section{Critical Reflection and Reflexivity}

Critical reflection was a central methodological component before, during, and after our engagement experience on the Reservation and was crucial in building an anti-racist and anti-colonial framework (Adams \& Bell, 2016; Kishimoto, 2018). In the classroom, this involved consistent reading and discussion of structural racism and settler colonialism, coupled with activities and exercises for connecting our own placed-based racial identities to these larger social structures. It was also important that $I$, as the instructor, fully participated in this process with students to help model this kind of reflection. My participation was meant to disrupt the power dynamics between myself and students by acknowledging that I, a white-identifying female professor, was still a student in this work along with them.

During our week of engagement on the Reservation, I intentionally set aside times for us to seek out a quiet space on Henry Red Cloud's sprawling property to reflect on our engagement experiences. Afterward, before going to bed, we gathered as a group and shared some of our reflections with one another. Our course culminated in a final 12-page community engagement portfolio in which students were asked to critically reflect on their entire engagement experience on the Reservation by (a) connecting their experience to course theories and concepts, (b) offering reflections and observations that include their own learning but prioritize the experience of Pine Ridge community partners as much as possible, (c) discussing how they see themselves using what they have learned in their future lives, and (d) reflecting on the concept of place and how it has informed their engagement experience. I received permission from these 10 students to quote from their portfolios and from focused in-class reflections. Below, I draw from these responses to assess and reflect on students' experiences.

In anthropology, critical reflection, or reflexivity as it is referred to in the discipline, has been a central methodology employed by anthropologists since the 1980s as a way to acknowledge the subjective nature of doing cultural research. Reflexive writing includes the researcher's experiences, along with a careful awareness of how the researcher's own identity and presence might inform their work with, and representations of, others. In my own work, this involves a delicate balance between acknowledging one's own social position, thoughts, and emotions while also uplifting the voices and perspectives of those we work with.

In the spirit of reflexive writing, I want to acknowledge here that doing community engagement on a Native American Reservation and writing a peer-reviewed article about this experience is laden with complications. One of my goals for teaching the course and writing this article was to include Lakota voices, to disrupt common misconceptions and stereotypes, and to actively accept the role of our community partners in the practice of 
teaching. However, I am also working within an academic structure that is the product of a Eurocentric history. My attempt to honor the authority of Indigenous knowledge in this work is to include Lakota concepts and stories alongside the academic concepts and readings we used in the classroom. These stories were openly shared with us while on the Reservation and provide valuable lessons in and of themselves. There are also stories I have chosen to leave out because I do not feel that they belong here in the pages of an academic journal. This is where I must reflect on my own authority as an anthropologist and how I choose to translate and represent cultural experience. I also recognize that this article is written for an academic audience. This was most evident when I shared drafts of this article with the community partners whose names I include and/or with whom we worked most closely. Even though I did not receive any openly negative feedback, sharing this work with Pine Ridge residents heightened my experiences of disconnect between academia, academic writing, and the realities of the Reservation, and while I cannot speak for community partners, I could not help but wonder if they felt this same disconnect when reading this article. Although this article highlights student learning and draws heavily from student reflections as well as my own where appropriate, I include Lakota concepts and some of the stories we encountered on the Reservation in an effort to demarginalize Native voices and acknowledge storytelling as a powerful decolonizing tool (L. Smith, 2012; Tuck \& McKenzie, 2015).

\section{Embracing Place}

Anthropologist Keith Basso (1996b) writes that "what people make of their places is closely connected to what they make of themselves as members of society and inhabitants of the Earth" (p. 54).

In preparing students for critical community engagement on Pine Ridge Reservation, students were guided toward understanding the Reservation as a place rather than simply a "placement site" (Siemers et al., 2015). Two academic concepts helped to facilitate this conversation-sense of place and place attachment. Sense of place refers to "the ways in which citizens of the earth constitute their landscapes and take themselves to be connected to them" (Basso, 1996b, p. 54). Similarly, Low (1992) describes place attachment as the emotional and symbolic relationship between people and land. The connections that people have with land, she argues, may stem from six kinds of relationships: genealogy, loss of land, cosmology, pilgrimage, economic relationships, and cultural narratives and place-naming. All of these relationships are clearly evident in the case of the Lakota and their attachment to the land.

Established in 1889 as Prisoner of War Camp \#334, Pine Ridge Reservation is made up of approximately 2.1 million acres of land, most of it wide, open landscapes of rolling grassy prairie. Weather patterns are often severe with harsh winds and brutal seasonal extremes. There is one major highway and one major grocery store serving the entire Reservation of roughly 20,000 people (U.S. Census Bureau, n.d). ${ }^{1}$ Adding to this isolation, homes on the Reservation are spread out over vast distances from one another, and the closest city, Rapid City, is 120 miles away. Once part of the Great Sioux Reservation, Pine Ridge is small in comparison to the original territory that

1. There are conflicting statistics on the population of the Reservation itself. Estimated tribal enrollment of the Oglala Lakota is 46,000 (Bureau of Indian Affairs, n.d.). 
was set aside by the U.S. government with the revision of the Treaty of Fort Laramie in 1868. This land would later be parceled out into private allotments under the Dawes Act of 1887 , with the remaining millions of acres of some of the best farmland opened up to white homesteaders. However, as noted in the introduction, this loss of land goes much further back.

Genealogical place attachment refers to a long-standing historical identification people make between land and community (Low, 1992). The Lakota occupied and used vast territories of the northern plains for centuries, including the Black Hills (Paha Sapa), a mountain range that is the sacred center of the Lakota universe (Gonzalez, 1996; Ostler, 2010). Low (1992) also notes that the loss of land creates another form of place attachment that is deeply tied to a people's sense of identity, becoming encoded in their cultural practices. As mentioned previously, the Black Hills and other nearby sacred sites were seized from the Lakota by the U.S. government after breaking legal treaties. ${ }^{2}$ Much of this lost land is now under the management of state parks such as Badlands and Wind Cave National Park, as well as the ironically named Custer National Park. This is certainly relevant to the Lakota as the phrase "honor the treaties" is commonplace, from bumper stickers to chants during pipeline protests (i.e., nearby Standing Rock). Indeed, part of being Lakota is a deep awareness of this loss of land. The Lakota have a primordial connection to their lands, often traveling to the Black Hills and other nearby sacred sites for vision quests and other religious rituals. ${ }^{3}$ This attachment to place through cosmology and pilgrimage bind people to their landscape through religious and spiritual conceptions of the world (Low, 1992). This is most indicative in the Lakota prayer Mitakuye 'oyasin, meaning "all my relations," which is meant to invoke and honor the divine relationships between all things animate and inanimate.

Another way in which people create attachment to place is through their economic relationships, which is often expressed through ownership or rights over land (Low, 1992). It is important to note that the Lakota do not view land as property; rather they were forced into an economic relationship with the land in an attempt to assimilate them into the mainstream U.S. economy through wage work and agriculture (Pickering, 2004). Russell Means, a Lakota writer and activist born on the Reservation, explains, "One must understand that to an Indian, ownership of land is a foreign concept. The earth is our grandmother, who provides us with everything we need to survive. How can you own your grandmother? How can you sell her?” (Means, 1995, p. 10). In the traditional Lakota worldview, land is imbued with wakan, or power, and gives life and sustenance to all living things (E. Deloria, 1998), but it has also become a powerful symbol of tribal sovereignty and self-determination (Grande, 2004).

Lastly, Low (1992) discusses the importance of naming and cultural narratives in creating a sense of place and attachment to the landscape. Basso (1996a) notes that on the Fort Apache Reservation in Arizona, remembering place-names and recounting stories about places are mediums of ancestral authority for the Western Apache,

2. In 1980, the Supreme Court ruled that the U.S. government's seizure of the Black Hills in 1877 was a violation of the Fifth Amendment's sanction against taking property without due compensation and awarded the Lakotas and other Sioux tribes $\$ 102$ million. The Lakota rejected this offer citing, "The Black Hills are not for sale."

3. The Lakotas view the Black Hills as sacred, but not to the exclusion of other landscapes. As there is no distinction between sacred and profane in the Lakota worldview, all things are imbued with wakan (mystery, power). But as Ostler (2010) notes, "the Black Hills contained a singular density and variety of wakan places and beings, like the Thunder beings or the buffalo, who had emerged through Wind Cave, and were an especially charged landscape.” 
who deeply engage with the landscape as a necessary means of obtaining and passing on cultural wisdom. Conceptions of place on Pine Ridge Reservation are woven into the stories that elders generously share. These stories serve as Indigenous tools for teaching and learning (Kovach, 2009; McNally, 2004) as well as counter-narratives (Solórzano \& Yosso, 2002) to dominant settler discourse. They may be verbal, as in the use of the Lakota language and the telling of stories, myths, and histories, or they may include other performances, such as powwow dances or the making of arts and crafts (Smith, 2012). Places are made of stories (Bird, 2002). "The story and the story teller both serve to connect the past with the future, one generation with the other, the land with the people and the people with the story” (L. Smith, 2012, p. 146).

Upon our arrival during our 2018 visit, the Reservation had recently endured a major hail storm that left the siding of many of the houses and trailers pocked with holes and the sprawling corn fields violently shredded. It was snowing hard by the time we crossed onto official Reservation land in our rented 15 passenger van. I turned the radio to KILI, “The Voice of the Lakota Nation," a non-profit radio station run from the Reservation and a place that we would soon discover would be on our agenda for community engagement in the coming days. KILI radio provides a powerful sense of place on the Reservation as it connects residents who are spread out over large distances, providing local Native news and politics and disseminating Lakota voices and narratives. The resonating drum beats and high- pitched singing of powwow music emanating from the van speakers indicated that we had indeed crossed a social border (Hayes \& Cuban, 1997).

This sense of border crossing is highlighted by a radical shift in the practice and experience of time. In an article previously discussed in class, Pickering (2004) notes the prevalence of "task-oriented time" on the Reservation in contrast to the "clock time" that is highly valued in the larger capitalist economy. The former makes very little separation between work and daily life, and the tasks themselves determine the pace and intensity of work. Clock time, however, is a quantified commodity that is intentionally separated from social relations and designed to get the most production out of human labor. Vic Glover (2004), a resident of the Reservation, describes this time shift on the Reservation beautifully:

Welcome to Indian country. Suddenly the land opens up and yawns out, and remote, isolated trailer houses supersede the split-level homes south of the line. ... Welfare state poverty replaces productivity and the American dream. Spirituality supplants religion. The curtain is lifted. Tight schedules yield to Indian time. (p. 136)

On day two of her daily reflection while on the Reservation, one student comments on her experience of this shift from clock time to task-oriented time:

I've started to notice the task-oriented time on res, where everything just happens as it comes. All of our plans seem to change constantly, yet all the things that need to happen do happen. Everything feels much more relaxed and less forced as we allow things to happen in the most sensical way as opposed to being tied to a constructed idea of productivity. 
Being in a place, experiencing its ecology, feeling its rhythm, hearing its stories, and connecting with those who live there is a particular kind of learning that has more than one teacher. In other words, place teaches us. In reflecting on the role of place in her experience of community engagement, Sierra writes:

Doing the work of studying place in conjunction with community engagement helped me to be a more intentional steward to my surrounding environment and to be a more respectful visitor on the Reservation.

Her words echo Gruenewald's (2003) claim that "a critical pedagogy of place ultimately encourages teachers and students to re-inhabit their places, that is, to pursue the kind of social action that improves the social and ecological life of places, near and far, now and in the future” (p. 7).

When I first took students to Pine Ridge in 2016, we arrived on the Reservation at the height of the protests against the Dakota Access pipeline on the nearby Standing Rock Reservation. Many residents of Pine Ridge Reservation, including some of our community partners, had traveled to Standing Rock to support and stand in solidarity with the "water protectors" there who were fighting to maintain the health of their water. We were invited by our community engagement organizer to hand paint phrases such as "no DAPL" and "honor the treaties" on banners and bandanas to be used in the protests. ${ }^{4}$ Students took on this work with a great sense of responsibility and meaning. Already knowing the relationship that Indigenous peoples have with the land and the countless examples of this relationship being historically compromised, students saw their artistic work as a collaborative effort to protect place and to support the Lakota in maintaining their attachment to place. This speaks to the powerful potential that critical understandings of place have as a starting point for practicing critical community engagement.

\section{Embracing Race}

My schooling gave me no training in seeing myself as an oppressor, as an unfairly advantaged person, or as a participant in a damaged culture. (McIntosh, 1989, p. 10)

The Lakota word for "white people" is wasicu. This word is often literally translated as "fat-takers" but also connotes "loud talkers" and "one who takes the best for himself" (Petrillo, 2007, pp. 107-108). Over time it has taken on the more general meaning of "a mind-set, a worldview that is the product of the development of European culture” (Means, p. 28). In this vein, while it does not necessarily connote the color of one's skin, it is still deeply tied to the concept of whiteness (Lipsitz, 2006). On the Reservation people may speak of wasicu ways or the wasicu world, and it is a word that students should understand and expect to hear. In fact, it is nearly impossible to visit the Reservation and not be confronted in some way by the social realities of race.

4. Because of the political nature of this engagement, students were not required to participate and were not graded based on their decision. However, all students chose to be involved, and one student organized their own Standing Rock rally locally upon returning home. 
In order to prepare students for discussions of race in the classroom, I begin with radings and in-class exercises that are designed to critique white normativity in the United States. This includes Peggy McIntosh's (1989) classic article on white privilege and Robin DiAngelo's (2011) discussion of white fragility. These readings are relatively easy for students of varying disciplines to understand (at least cognitively) and provide a starting point for deeper discussions of how race and place intersect. Students are encouraged to think of white privilege as hidden, "unearned advantages" and "conferred dominance" based on one’s skin color (McIntosh, 1989). In conjunction with this, the concept of white fragility aids students, particularly those who identify as white, in expecting discomfort and defensiveness due to a lack of "stamina" in being able to talk about race or deal with racial stress (DiAngelo, 2011). ${ }^{5}$ In addition to reading these articles together, we practice a series of identity exercises that require us to think deeply about our own racial identities and potential privileges. ${ }^{6}$ Below are a few examples of how students grappled with these aspects of the class:

As a class, we had to understand how we benefit from white privilege and sit in the discomfort of knowing that we each have a hand in cultivating and maintaining the social field of whiteness ${ }^{7}$ whether we like it or not. - Hannah

While these articles were heavy, and informative, it was also scary for me. I was stepping outside of my comfort zone and reading information that I have never seen or discussed before in my life. I questioned my privilege, my identity, my parent's identities, and the small southern town that I grew up in and love (for the most part). But by sitting in this uncomfortableness, I was able to come to terms with a reality I have had trouble coming to terms with. - Anna

To me, one of the most important parts of the course and our trip to Pine Ridge, was being forced to confront my own whiteness and reckon with that history on a personal level. Often when I have learned about racism and especially the history of racism in America, I have rarely had to conceptualize how that history is reflected in my own life and in my own personal actions. - Ian

Critical community engagement demands a willingness to self-critique as well as being open to outside critique. This involves more than a critique of one's own social privileges. It includes a critique of the very practice of community engagement and service learning as well as critiquing academia as a product of settler colonialism and white supremacy (Illich, 1990 Mitchell, 2008; Patel, 2016; Santiago-Ortiz, 2019). This also inevitably means

5. I do not mean to imply that confessions of one's privilege or fragility should necessarily be considered an anti-racist act. See Lensmire et al. (2013) on their critiques of the overuse of McIntosh's article in doing anti-racist work. However, it is an important step in the much larger process of doing this work.

6. This particular year there were six students identifying as white and female, one as white and male, one as African American and male, one as Native American (Diné) and female, and one female identifying student of Romani descent.

7. The concept of the "social field of whiteness" comes from Hargrove's (2009) article addressing urban renewal and heritage tourism's effects on the Gullah/Geechee community in Charleston, South Carolina. 
being willing to critique the very discipline from where one teaches. As an anthropologist whose discipline has historically been implicated in perpetuating narrow representations of Native Americans and other groups through a white normative lens (V. Deloria, 1969), I want students to be aware of these critiques before reading more contemporary examples of the anthropology of race and place. It is also important that we understand how this complex disciplinary history might shape and influence our engagement on the Reservation. ${ }^{8}$ Lakota activist and professor Vine Deloria Jr.'s witty and scathing essay “Anthropologists and Other Friends” (1969) is an important start to this conversation. He writes:

Academia, and its by-products, continues to become more irrelevant to the needs of people. The rest of America had better beware of having little quaint mores that will attract anthropologists or it will soon become victim of the conceptual prison into which Indians have been thrown. (V. Deloria, 1969, p. 93)

Deloria's unapologetic critique can be hard for those of us in academia, and particularly anthropologists, to read. Yet a crucial component in anti-racist teaching involves humility, critical self-reflection, and an embracing of outside critique. This willingness to be vulnerable, particularly on the part of educators, can also help to level power dynamics and build a sense of community and collaboration in the classroom and other spaces of learning (Kishimoto, 2018).

Another common practice in social justice work involves the deconstruction of binary categories (Adams \& Bell, 2016). Community engagement involving Indigenous communities demands that we scrutinize the Black/ white racial binary that is common in the United States by acknowledging how settler colonialism has informed and continues to inform the experience of Indigenous peoples. Students must come to understand settler colonialism as a product of white supremacy that is related to, but not the same as, racial discrimination as well as a process that requires the erasure of Indigenous people, their places, and their stories (Dunbar-Ortiz, 2014; Smith, 2012).

While the academic concepts and readings mentioned above were meant to aid students in sitting with their discomfort and reflecting on issues of privilege and power, experiencing Pine Ridge Reservation as place and hearing firsthand from Lakota elders living there furthered this learning in a much more meaningful way. In the next section, I explore further the following common themes that emerged from our community engagement experience on Pine Ridge Reservation:

- owning the discomfort of privilege (including academic privilege),

- experiencing the reality of "survivance" among marginalized peoples (Vizenor, 2008), and

- the centrality of place-based stories for reciprocity and allyship.

8. Some of the students told me that while I was helping to cook food in the kitchen during an engagement, an elder asked the students about their majors. When some of them mentioned anthropology, he responded with "Anthropologists? They're the worst!” Maria told me that she laughed and said, "We are trying to change that." She writes in her reflection, "He shared with me that he really believes in the youth today, and urged me to lead a life with purpose." 


\section{Wasicu at Wounded Knee}

As we sit in a circle in the cool, dry hemp house of Debra White Plume's property along the banks of Wounded Knee Creek, she begins by telling us, "I don't consider myself to be an activist. I consider myself to be a good relative to Mother Earth and all of her children." Born and raised on the Reservation, Debra is a community organizer and proponent of Indigenous Rights and the revitalization of Lakota Culture. Here on her land, she has created Ama's Freedom School, a place where Lakota youth are taught a Lakota curriculum designed to supplement their regular schooling and re-connect them to their ancestral way of life. On the wall behind us there are posters written in children's handwriting describing the importance of the buffalo to the Lakota Nation. Debra continues by addressing the loss and environmental destruction of surrounding Native lands by nonNatives with intense focus. Occasionally she stops to ask direct non-rhetorical questions to individual students and waits for an answer. After taking a sip of her coffee, she continues:

I love the Earth, I want to take care of the Earth. When they decided to mine Uranium and gold in our Black Hills, they poisoned the water with cyanide and they ruined it forever. I often imagine how horrible it must have been to be a Native back then and feel like there was nothing you could do.

Turning to a student, she asks:

Do you think it would be traumatic for you if two men took your mother into the other room and locked the door and raped her? Because that is how it would feel. Do you think you might have some trauma? We call it historical trauma.

We listen quietly as she speaks about race and settler colonialism, the loss of Native lands and oil pipelines, and the concepts of wasicu and Mitakuye 'oyasin. She tells us that when the white man first showed up, they did not refer to the color of his skin. They called him wasicu, or fat taker. In the olden days, women would spend weeks preparing animal fat, which they used to help their families survive. They would make lanterns and foods with it and they would hang it outside their tipis to prepare it. But one day a white bearded man with messy hair, who had gotten lost and become hungry, came upon this fat and he stole it, never noticing the village of tipis that were spread out on the other side of the hill. "Wasicu was meant to describe these people," she tells us.

After two hours of listening to Debra and sharing a meal with her and members of her family, she looks at me and asks sternly, "Why do you want to go to Wounded Knee?" knowing that this is next on our agenda for the day. I nervously tell her that I felt it was important for students to understand what happened at this site and to understand it as a place of contestation, cultural memory, and survival (albeit probably not as articulately put at that moment). The national historic site of the 1890 Wounded Knee Massacre, just south of Debra's land, has come to be known as a leading symbol of the United States' racist and dishonorable treatment toward Native peoples. As many as 300 unarmed Lakota men, women, and children traveling with Chief Big Foot under a 
white flag of truce were killed by the U.S. 7th Cavalry and buried in a trench close to where the historic site is located (Brown, 1970). Today the burial site has grown into an active cemetery that encircles a tall grey monument, erected by the Lakota in 1903 to honor the victims of the massacre (Grua, 2016). Across the road is a parking lot and an informational sign. ${ }^{9}$

Debra did not agree that we should visit the site. Maria described and reflected on this experience:

She snapped at us and told us that white people have no business at Wounded Knee, and it would be incredibly disrespectful for us to visit there when we have no personal connection to that site aside from our participation in settler colonialism. When we returned to the van we had a long discussion on whether or not we should go. I felt a desire to go, but I realized that the desire came from a selfish place of not wanting to be deprived of an experience I was expecting to have. We decided that we would go read the sign across the street from the burial site, and to see the site from afar.

Lakota attitudes toward non-Native outsiders visiting the Wounded Knee site are indeed mixed, and we had discussed this a few days before as we sprinkled tobacco into the prayer ties that we planned to take with us to the site as a sign of respect. While we sat in the van reflecting on Debra's words, we came to the eventual compromise to stop at the parking lot across from the cemetery and carefully and critically read the informational sign there. Here students commented on the Eurocentric tone of the sign's historical description of the event, noticing where the word "battle," originally used by the Department of War, had been covered up with the word "massacre" as a more accurate description and a revising of this settler colonial narrative. Later that evening, the students and I had a long discussion about our choice to not visit the cemetery and how Debra's concerns and all of her teachings that day were tied to concepts of privilege.

This day was filled with us being forced to analyze our white fragility/white privilege, because she spoke to us directly and unapologetically of the pain and destruction brought on by whites, and that we were not separate from that. - Maria

After the conversation with Debra White Plume, I spent a lot of time thinking about racism on a personal level, in a way that I have rarely had to do before. I believe that the shock I experienced at Debra's was what DiAngelo recommended, "it is critical that all white people build stamina to sustain conscious and explicit engagement with race” (DiAngelo, 2011, p. 66). - Ian

It takes privilege to be able to leave behind our $\$ 40,000$ per year liberal arts college and just be with the Lakota for a week. We brought our privilege on this trip, and along with our privilege came dietary restric-

9. The Wounded Knee Massacre site also became a site of political occupation by members of the American Indian Movement in 1973 in protest against a corrupt tribal administration and the U.S. federal government's failure to honor its treaties with Native Americans (see Crow Dog, 1990; Reinhardt, 2007). Debra White Plume was involved in this occupation as well. 
tions and desires for a new cultural experience. Debra pointed out our privilege of curiosity when she asked why we were going to Wounded Knee. Hearing her perspective on us not having the right to go to the site made me think that we don't need to be the wasicu of history for the sake of memorialization. We can memorialize Wounded Knee today by raising up the voices of the Lakota and spread the accurate history as well as aid in helping others understand the Lakota in a way our ancestors never did. - Hannah

While this moment was indeed uncomfortable because it openly exposed our racial, class, and academic privilege, it also became a moment in which these privileges were revealed as a position rather than an unchanging construct (Green, 2003). We gained an awareness that we could make different choices based on what we had learned and, as Hannah's quote suggests, a deeper sense of responsibility. As the instructor, I had to let go of my chosen agenda and fall back into the role of student. This was also a lesson about place and place attachment. We were outsiders, products of a settler colonial history, with no deep and ongoing physical and spiritual relationship to this place. In this case, paying one's respects to this place meant letting it be.

\section{The Reality of Survivance}

One of our engagements on the Reservation involved students floating in Lakota language immersion classes at a primary school and day care, assisting teachers and children, but without speaking English. Many students wrote about this experience, seeing the teaching of the Lakota language as a reclamation of identity after a traumatic history in which boarding schools sought to strip these markers from Lakota children as part of a larger "civilizing mission.” After observing children reading in Lakota, Maria admitted, "This was when I really internalized the reality that Native Americans are not just what has been done to them during colonization.” Denia, a student of Diné descent wrote, "Making paper monsters may not have meant anything to the infants we helped, but I got to contribute and witness the reclamation of a language.” Eve, who was also placed in the day care, was deeply moved by her experience there:

Before these children ate their breakfast they knew to listen to the Lakota prayer and a girl less than two years old walked around with sage in an abalone shell as each child smudged themselves. The scene was so powerful and showed the fierce resiliency of the Lakota in the context of genocide, colonization, oppression, and assimilation.

Spending a full week listening to Lakota prayers and stories, cooking and eating traditional meals, observing and participating in traditional music, dance, games, and crafts certainly brought to light for students a strong sense of perseverance, or what Anishinaabe scholar Gerald Vizenor (2008) calls “survivance” (survival as resistance). For Linda Tuhiwai Smith (2012), survivance "accentuates the degree to which Indigenous peoples and communities have retained cultural and spiritual values and authenticity in resisting colonialism” (p. 146) and provides a "language of possibility, a way out of colonialism" (p. 204). This “active Native presence" (Vizenor, 2008) is 
undeniable on the Reservation and, for non-Native outsiders, is a reminder that the Lakota and their culture are here existing in the present and are not vanishing, as settler colonial representations would have us believe. This is poignant in Anna's final reflection:

You can read about a nation or group all day long but it does not compare to living with them and sharing stories and meals with them. They encouraged us and while they told their stories of struggle, they made sure to let us know that they are optimistic and fighting for what is right. I think that is what books and research fail to mention and show is the personal stories and aspects of life now instead of things past oriented. That's one big takeaway that meant a lot to me. - Anna

Lakota survivance became a powerful mobilizer for students in being more aware of, and critiquing, settler colonial and white normative representations that we would encounter later when traveling off the Reservation. On our last day in South Dakota, we left the Reservation and drove through the Badlands and then to the Crazy Horse Memorial located in the Black Hills. ${ }^{10}$ The memorial of the Lakota warrior known for defeating Custer and his 7th Cavalry at the Battle of Little Bighorn is also a highly contested place for the Lakota. While some see it as a Native alternative to Mount Rushmore and a celebration of Native resistance, others view it as simply another way in which non-Natives are capitalizing off of Native American genocide. For example, on our last morning on the Reservation, as we headed out to visit the memorial, our engagement coordinator tells us that Crazy Horse should be honored but not by having his image blasted into the side of a mountain. "This is not what he would have wanted.” After visiting the Native American Museum at the Crazy Horse Memorial, Maria wrote:

After having spent a week with Lakota people, sharing meals with them, hearing their stories, being invited into their homes, hearing their language, sharing in prayer with them, and being able to participate in their culture, it was disgusting to see them and other Native peoples immortalized as a thing of the past.

Students also commented on the tourist representations they encountered during our road travel.

On the way to the Crazy Horse memorial one can see hundreds of advertisements offering sugarcoated representations of the Cowboys and Indians narrative. Billboards offered Eurocentric narratives glorifying "Gold Rush" themed establishments, "Indian" village tourist attractions, and "Wild West" towns. These institutions reinvent the "Western Frontier" a popular narrative that reinforces notions of colonialism and America's "Manifest Destiny." - Sierra

10. My goal in visiting this site was for students to get a better sense of the contested nature of place but also to experience these outsider representations. I knew that the memorial would most likely be a stark contrast for them after having been on the Reservation for a week. Our community engagement coordinator agreed that it would provide a contrasting perspective after all their time on the Reservation. 
On our return to the airport in Rapid City, we were met with visual surprise from the rental car agent and hotel clerk when we spoke of our time on the Reservation as a positive educational experience. Sierra addressed this in her final reflection:

Most non-Natives who we interacted with during the trip carried decidedly negative perceptions about the Rez, regardless of whether or not they had spent time there or not. I was reminded of Peggy McIntosh's White Privilege, wherein she writes “. . . whites are taught to think of themselves as morally neutral, normative, and average, and also ideal, so that when we work to benefit others, this is seen as work which will allow "them" to be more like "us" (McIntosh, 1989, p. 10).

The positive realities that students experienced on the Reservation were decidedly absent in spaces and representations off the Reservation, and students began to connect this to critical theory from our class. They aligned these negative and static representations with the structure of settler colonialism and its enduring legacy of the “disappearing of the prior existence of Indigenous peoples” (Dunbar-Ortiz, 2014, p.9). Experiencing Lakota survivance had an immense impact on the students as they struggled with how to use this knowledge going forward.

\section{Reciprocity and Allyship}

Most everybody who comes rolling through here takes back more with them than what they brought. (Glover, 2004, p. 28)

I feel like we gained so much more than we gave. - Eve, student

With snow under our feet from the day before, we help Henry Red Cloud cut firewood for his woodstove as well as for ours. As we take turns splitting the thick tree stumps, he tells us about his recent work helping to get KILI radio fully solar powered and his current program designed to train other tribal members in solar technology as a new path to tribal sovereignty and a way to lower "our carbon moccasin." Later in the week, we help Henry replace the siding of his trailer that had been ravaged from the hail storm months prior. In between sawing panels, he shares with us the work he has been doing in planting thousands of Ponderosa pine saplings at Bear Butte, a sacred site that had been burned by wildfires. "We worked hard planting about 5,000 trees. It was so nice. There were folks doing vision quests out there. And we slept out there at night, with the moon as our pillow and the stars as our blankie.”

It is these place-based narratives that students come to accept as valuable cultural knowledge given to them not necessarily in return for their community engagement work but as a product of their engagement work. For instance, while giving the inside walls of KILI radio a fresh coat of paint, a volunteer DJ shared stories with us about his time as a tribal police officer on the Reservation in the 1990s and the problem with drugs and alcohol on the Reservation, admitting to once putting his own mother in jail for intoxication. And after participating 
in a two-hour beading workshop with an elder, students cherished this woman's dry sense of humor and the personal stories she shared with them about family, her earlier struggles with alcoholism, and the importance of crafts.

Eve, the student quoted above, echoed a sentiment that many of the students in my course shared once we had returned from the Reservation. During our last meeting together as a group, several of the students expressed hesitation in highlighting their work on the Reservation, focusing instead on the stories they heard and the lessons they learned from elders. They had experienced an immense amount of wówačhantognake, or generosityone of the seven Lakota values. They all agreed that they felt their service was less about the labor they brought to the Reservation and more about the space they held for elders to share knowledge with them. They also pondered how they might subsequently utilize this knowledge to de-center dominant settler-colonial discourse in their future lives.

Indigenous scholars acknowledge the value of stories as a methodology for teaching, as it often creates respectful and reciprocal relationships between storytellers and their listeners (Archibald, 2008; Kovach, 2009; Smith, 2012). While storytelling is an important way in which elders pass on the beliefs and values of their culture to the next generation, during community engagement, it also serves to de-center settler colonial narratives and representations. These "counter-stories" expose and challenge the "majoritarian stories of racial privilege" (Solórzano \& Yosso, 2002).

Students valued these stories to such an extent that many of them queried ways in which they could return the Lakota generosity that they experienced. They addressed this through philosophies of allyship and the re-telling of stories as a way to disrupt stereotypes and dominant narratives.

I really enjoyed all the stories I heard from the people we met on this trip and I will be sure to tell stories about this place that will paint it in a more positive light. - Darrin

Talking to people and spreading positive images and memories of what we experienced is important to many people on Pine Ridge and is maybe the best way we can give back. - Ian

One way that we can repay them and part of our responsibility in going forward is making sure that we advocate for more truthful, holistic representations of the folks we had the privilege of learning from. We owe it to them to be able to challenge misrepresentations of Natives and support Native issues as best we can, within our bounds as non-Native allies. - Sierra

In these cases, students made strong connections between listening to stories in place and being an ally-using these stories as a way to thoughtfully guide their future discussions and representations of place, (the Reservation), the Lakota, and Native peoples in general.

Critical community engagement should also work to disrupt the server/served dichotomy that can sometimes be implied in service learning practices. Despite our best efforts, students often tend to think about their service 
work as filling a need for those who are either economically or socially marginalized without necessarily being aware of what community partners offer in return. As Madsen Camacho (2004) notes, reciprocity is a crucial component of service learning that sets it apart from charity or philanthropic work; however, this reciprocity is often "asymmetrical” (p. 31). Rather than simply thinking of learning as the reciprocal exchange received by students who in return offer practical skills, physical labor, and educational knowledge to community partners, Lakota methodologies encourage students to see the value in simply holding space-as a willingness to open themselves up to the realities of the Reservation and what it means to be Indigenous in the United States.

It was abundantly challenging to me to not just apologize all day, to not be a walking-talking embodiment of white guilt. A lot of times, it was challenging to stay silent, but as the trip evolved, I found immense comfort and gratitude in my silence. - Brianna

We feel this need to be constantly working and "giving” something, but often doing nothing, and listening are some of the most important learning experiences and the real things that we can do to make ourselves useful in situations. The amount of time we spent listening and spending time with people really changed my idea of community engagement, moving it away from doing and more towards being present and holding space. - Maria

I used to think that service was all about helping those less fortunate than I but I have come to the realization that it's not. Hearing stories from members of the community that we are engaging with are just as important if not more so. It's one thing to go engage and not hear any stories and then come back and say “eh, we didn't really do anything. I don't see how stacking wood is going to do them any good.” But it's another to listen and come back and say "What now? What can I do now to continue my engagement even if it is from afar?” I am constantly asking myself "What now? What now? What now?” —Denia

Denia's concerns about what to do next speaks to the role of allyship in giving back to the communities we engage with. If we accept that critical service learning should help students in cultivating a critical consciousness and empowering them to become agents of social change for the future (Mitchell, 2008), then it is important to highlight the value of the placed-based stories, wisdom, and knowledge that students receive, particularly in how they might shape and influence their future roles as allies. This is particularly the case when doing service work with Indigenous communities, where the sharing of knowledge and tradition is also coupled with a sense of responsibility and stewardship (Grain \& Lund, 2016; McNally, 2004) — an expectation that this knowledge be used to promote the well-being of the community well after the community engagement experience is over. For example, after her two-hour long sit with students, Debra White Plume asked students to write a reflection of what they had learned in their time with her that day, already instilling in students a sense of responsibility in carrying forth the wisdom that was shared with them. Students spent their last few days in South Dakota writing these reflections knowing that they would be read by her, as an elder, and they took great care in their writing. 
Working toward being a responsible ally should not only be expected of our students. Faculty and other community engagement facilitators must be willing to model this as well. During the spring semester following the course and our engagement at Pine Ridge, the students and I presented on our experience at the college's annual campus-wide capstone event. Even though the students were busy with other classes and research projects, all but two of them participated in the presentation, including a student who had already graduated in December. The room was packed with faculty, staff, and students, and we shared stories with the utmost sense of responsibility. The Reservation had also recently experienced a bomb cyclone that caused catastrophic flooding, leaving some residents stranded in their homes for weeks. One of these residents was Henry Red Cloud, whose property, including the building that lodged us during our time there, was under 3 feet of water for days. We ended our presentation with a request for donations, and in the weeks to come, some of the students and I continued our fundraising efforts.

As one student wrote in their final engagement reflection, "Thinking of the trip as over would be wrong." Many students continued this sense of responsibility after our engagement. One student who went on to work at a national park out west, wrote me a frustrated email about how little her co-workers were willing to address the erasure of Native history in the park and wanted to figure out how to do more. I returned to the Reservation a few months later to help Henry with rebuilding after the floods. This article is also my own attempt to give back and to share the lessons learned while on Pine Ridge.

\section{Final Reflections}

Adams and Bell (2016) note that social justice is about both resources and recognition; that is, it must work toward an equitable distribution of resources as well as a recognition and respect for marginalized groups. In terms of resources, I confess that our week-long engagement on the Reservation made very little measurable change for its residents. Community partners were paid more than fair wage for their time, but we did not lay any groundwork for economic justice on the Reservation. While some of the students organized and participated in political protests around Indigenous rights and land protection as a result of their engagement, this did not necessarily lead to political justice for the Lakota either. Social justice work is rarely immediate; it is complex and ongoing. However, I do believe that we made progress in the work of recognition and respect-of Lakota experiences, histories, values, traditions, and struggles. Developing a critical consciousness around settler colonialism, Indigenous sovereignty, and self-determination, as well as gaining practice in being an accountable and responsible ally to those we engaged with, were the most obvious takeaways for students and myself.

I am aware of the critiques of the kind of community engagement that focuses heavily on student learning over the experiences and benefits of the communities we work with (Mitchell, 2008; Wade, 2000). In this article, I have tried to address this, somewhat, by including Lakota voices and stories and, when on the Reservation, by listening and following the lead of our partners in deciding what we should do and what we should know and hear. To be honest, it was much easier for me to assess what students learned than how our community partners benefited. Developing a way to assess and measure the benefits for our Lakota partners was much more complex, 
nor did I feel comfortable going to the Reservation to measure anything. What stands out the most as a benefit with the potential for long-term change that was continually alluded to on the reservation was allyship. A Native resident told me one evening after leading the students through a round of Lakota hand games-a highly performative team guessing game involving traditional song and dance-“see, you can't ask Grandfather Google everything. You have to come and see it for yourself, be in the moment, see the stars in the sky and listen to the stories. Go back and let folks know we aren't just suffering here.” For him, learning in and through place was the best way to understand the reality of the Reservation, which came along with an expectation that we work to responsibly represent this reality off the Reservation. These stories in place re-center the Lakota experience helping to counter stereotypes and other legacies of settler colonialism that continue to shape stories of this place.

A critical community engagement that is anti-racist, anti-colonial, and place-engaged should inevitably include invitation to the places we visit, an awareness and critique of social privileges (including academic privilege), and an acknowledgment of the survivance of the peoples we engage with, rather than just their experiences of pain and hardship. It should also work toward transgressing the server/served divide by highlighting the place-based stories that are shared during the engagement and by emphasizing reciprocity and allyship. I leave you with two more student examples:

Going to Pine Ridge and learning from the Lakota brought to life concepts of food insecurity, assimilation, territory disputes, settler colonialism, but also a fierce resiliency. I learned more about my government and more about myself, and all of it was because of the kindness and wisdom of the Lakota people who allowed us into their space and showed us their knowledge and crafts despite centuries of injustice perpetrated against them by people who look like me and like us. - Eve

The story that sticks out the most in my mind was one that Henry told about growing up on Pine Ridge. In their house, Henry and his family had a woodstove that they used for both heating and cooking. It was a great big thing that you could use to heat the house and to cook with. They would take it outside under the tree so that his grandmother could cook out there. Eggs and bacon for breakfast in the summer. He was cutting wood and kept insisting that we take a good amount as it was going to be very cold at night for the next couple of days. This kind of well-meant nagging on our wellbeing is something I would imagine grandparents would do to their children and grandchildren, it made me feel touched. - Darrin

Perhaps another way for academia to think of critical community engagement is that it is, to use the words of Debra White Plume, about being a "good relative."

\section{Addendum}

While I was writing the revisions for this article, Debra White Plume died of cancer. The New York Times published an article on her life of activism, referring to her as "defender of her tribe" (Astor, 2020). When she ques- 
tioned my choice to take students to the Wounded Knee site, because we had "no business there," it was easy for me to follow this with the question "What business do we have on the Reservation at all?" And yet, Debra invited us into her space and sat with us for hours telling us stories of Lakota history and the struggle to protect Native lands and Mother Earth. I remember thinking to myself, Debra is "schooling" us. It clearly mattered to her that she share this knowledge, to school us in her own way with the stories she felt we should hear. I am honored to have been "schooled" by Debra White Plume, and I will work in my own ways to keep these lessons alive.

\section{Notes}

I would like to express my deep gratitude to the residents of Pine Ridge Reservation for their immense generosity. Wopila tanka. I dedicate this work to the memory of Debra White Plume and Floyd Looks for Buffalo Hand. I also want to acknowledge Dr. Kathryn Burleson, Wendell Robinson, and Trey Jones for deeply introducing me to Pine Ridge and to the students of this course for being willing to go along with me on this learning journey. Lastly, I extend thanks to the Community Engagement Office at Warren Wilson College for their support, to all the various donors who have helped to sustain this program over the years, and to the anonymous reviewers and journal editors for their insightful feedback on drafts of this article.

\section{References}

Adams, M., \& Bell, L. A. (2016). Teaching for diversity and social justice (3rd ed.). Routledge.

Archibald, J.-A. (2008). Indigenous storywork: Educating the heart, mind, body, and spirit. University of British Columbia Press.

Astor, M. (2020, November 27). Debra White Plume, defender of her tribe, is dead at 66. The New York Times. https://www.nytimes.com/2020/11/27/us/debra-white-dead.html.

Bailey, M. S. (2017). Why "where” matters: Exploring the role of space in service-learning. Michigan Journal of Community Service Learning, 24(1), 38-48.

Basso, K. H. (1996a). Wisdom sits in places: Landscape and language among the Western Apache. University of New Mexico Press.

Basso, K. H. (1996b). Wisdom sits in places: Notes on a Western Apache landscape. In S. Feld \& K. H. Basso (Eds.), Senses of place (pp. 53-90). School of American Research Press.

Bird, S. E. (2002). It makes sense to us: Cultural identity in local legends of place. Journal of Contemporary Ethnography, 31(5), 519-547.

Brown, D. (1970). Bury my heart at Wounded Knee: An Indian history of the American West. Henry Holt and Company.

Bureau of Indian Affairs. (n.d.). Pine Ridge Agency. https://www.bia.gov/regional-offices/great-plains/ south-dakota/pine-ridge-agency.

Clark, C., \& Young, M. (2005). Changing places: Theorizing space and power dynamics in service-learning. In 
D. W. Butin (Ed.), Service-learning in higher education: Critical issues and directions (pp. 71-87). Palgrave Macmillan.

Crow Dog, M. (1990). Lakota woman. HarperPerennial.

Deloria, E. (1998). Speaking of Indians. University of Nebraska Press. (Original work published 1944).

Deloria, V., Jr. (1969). Custer died for your sins: An Indian manifesto. University of Oklahoma Press.

Deloria, V., Jr. (2003). God is red: A Native view of religion. Fulcrum Publishing. (Originally published in 1972).

DiAngelo, R. (2011). White fragility. International Journal of Critical Pedagogy, 3(3), 54-70.

Dunbar-Ortiz, R. (2014). An Indigenous peoples' bistory of the United States. Beacon Press.

Feld, S., \& Basso, K. H. (Eds.). (1996). Senses of place. School of American Research Press.

Glover, V. (2004). Keeping heart on Pine Ridge: Family ties, warrior culture, commodity foods, rez dogs and the sacred. Native Voices.

Gonzalez, M. (1996, Winter). The Black Hills: The sacred land of the Lakota and Tsistsistas. Cultural Survival Quarterly, 63-69.

Grain, K. M., \& Lund, D. E. (2016). The social justice turn: Cultivating “critical hope” in an age of despair. Michigan Journal of Community Service Learning, 23(1), 45-59.

Grande, S. (2004). Red pedagogy: Native American social and political thought. Rowman \& Littlefield.

Green, A. (2003). Difficult stories: Service-Learning, race, class, and whiteness. College Composition and Communication, 55(2), 276-301.

Grua, D. W. (2016). Surviving Wounded Knee: The Lakotas and the politics of memory. Oxford University Press. Gruenewald, D. A. (2003). The best of both worlds: A critical pedagogy of place. Educational Researcher, 32(4), $3-12$.

Gupta, A., \& Ferguson, J. (1997). Culture, power, place: Ethnography at the end of an era. In A. Gupta \& J. Ferguson (Eds.), Culture, power, place: Explorations in critical anthropology (pp. 1-32). Duke University Press.

Hargrove, M. D. (2009). Mapping the "social field of whiteness": White racism as habitus in the city where history lives. Transforming Anthropology, 17(2), 93-104.

Hayes, E., \& Cuban, S. (1997, Fall). Border pedagogy: A critical framework for service-learning. Michigan Journal of Community Service Learning, 4, 72-80.

Illich, I. (1990). To hell with good intentions. In J. C. Kendall (Ed.), Combining service and learning: Crosscultural learning (Vol. 1, pp. 314-320). National Society for Internships and Experiential Education.

Kishimoto, K. (2018). Anti-racist pedagogy: From faculty's self-reflection to organizing within and beyond the classroom. Race, Ethnicity, and Education, 21(4), 540-554.

Kovach, M. (2009). Indigenous methodologies: Characteristics, conversations and contexts. University of Toronto Press.

Lensmire, T., McManimon, S., Tierney, J. D., Lee-Nichols, M., Casey, Z., Lensmire, A., \& Davis, B. (2013). McIntosh as synecdoche: How teacher education's focus on white privilege undermines antiracism. Harvard Educational Review, 83(3), pp. 410-431.

Lipsitz, G. (2006). The possessive investment in whiteness: How white people profit from identity politics. Temple University Press. 
Low, S. M. (1992). Symbolic ties that bind: Place attachment in the plaza. In I. Altman and S. Low (Eds.), Place Attachment (pp. 165-185). Plenum Press.

Madsen Camacho, M. (2004). Power and privilege: Community service-learning in Tijuana. Michigan Journal of Community Service Learning, 10(3), 31-34.

McIntosh, P. (1989, July/August). White privilege: Unpacking the invisible knapsack. Peace and Freedom Magazine, pp. 10-12. Women's International League for Peace and Freedom, Philadelphia, PA.

McNally, M. (2004). Pedagogy in the classroom: A service learning model for discussion. American Indian Quarterly, 28(3/4), 604-617.

Means, R. (1995). Where white men fear to tread: The autobiography of Russell Means. St. Martin's Press.

Mitchell, T. D. (2008). Traditional vs. critical service-learning: Engaging the literature to differentiate two models. Michigan Journal of Community Service Learning, 14(2), 50-65.

National Park Service. (n.d.). American history, alive in stone ... https://www.nps.gov/moru/index.htm.

Omi, M., \& Winant, H. (2015). Racial formation in the United States ( $3^{\text {rd }}$ ed.). Routledge.

Ostler, J. (2010). The Lakotas and the Black Hills: The struggle for sacred ground. Viking Penguin.

Patel, L. (2016). Decolonizing educational research: From ownership to answerability. Routledge.

Petrillo, L. (2007). Being Lakota: Identity and tradition on Pine Ridge Reservation. University of Nebraska Press.

Pickering, K. (2004). Decolonizing time regimes: Lakota conceptions of work, economy, and society. American Anthropologist, 106(1), 85-97.

Reinhardt, A. D. (2007). Ruling Pine Ridge: Oglala Lakota politics from the IRA to Wounded Knee. Texas Tech University Press.

Santiago-Ortiz, A. (2019). From critical to decolonizing service-learning: Limits and possibilities of social justice-based approaches to community service-learning. Michigan Journal of Community Service Learning, $25(1), 43-54$.

Siemers, C. K., Harrison, B., Clayton, P. H., \& Stanley, T. A. (2015). Engaging place as partner. Michigan Journal of Community Service Learning, 22(1), 101-104.

Smith, L. T. (2012). Decolonizing methodologies: Research and Indigenous peoples (2nd ed.). Zed Books.

Solórzano, D. G., \& Yosso, T. J. (2002). Critical race methodology: Counter-storytelling as an analytical framework for education research. Qualitative Inquiry, 8(1), 23-44.

Tuck, E., \& McKenzie, M. (2015). Place in research: Theory, methodology, and methods. Routledge.

U.S. Census Bureau (n.d.). 2015-2019 American community survey 5 year estimates. U.S. Department of Commerce Economics and Statistics Administration. https://www.census.gov/tribal.

Vizenor, G. (2008). Survivance: Narratives of Native presence. University of Nebraska Press.

Wade, R. C. (2000). From a distance: Service-learning and social justice. In C. R. O’Grady (Ed.), Integrating service learning and multicultural education in colleges and universities (pp. 93-111). Lawrence Erlbaum Associates.

Yamamura, E. K., \& Koth, K. (2018). Place-based community engagement in higher education. Stylus Publishing. 


\section{Author}

CHRISTEY CARWILE is Professor of Anthropology and Global Studies at Warren Wilson College. She received her PhD in Anthropology at Southern Illinois University Carbondale in 2007 after conducting field research on gender, indigenous religion, and the power of motherhood in southeastern Nigeria. She has published on religion and dance in West Africa and has employed dance and movement as a method for community engagement and critical reflection in her classes. Her current research examines the role of ritual, land, and place in genealogy and family history practices and explores methods for doing critical anti-racist genealogical research. 